\title{
Winter ontogenetic migrations and the onset of gonad development in large dominant calanoid copepods in the Weddell Gyre (Antarctica)
}

\author{
Vassily A. Spiridonov ${ }^{1, *}$, Ksenia N. Kosobokova ${ }^{2}$ \\ 'Zoological Museum of the M. V. Lomonosov Moscow University, Bolshaya Nikitskaya Str., 6, Moscow 103009, Russia \\ ${ }^{2}$ P. P. Shirshov Institute of Oceanology, Nakhimov Ave., 36, Moscow 117218, Russia
}

\begin{abstract}
Data on abundance, stage composition and vertical distribution, sex ratio, maturity states, and the inferred seasonal/ontogenetic migrations of Calanoides acutus, Calanus propinquus, and Rhincalanus gigas obtained during the Winter Weddell Gyre Study 1992 in early to mid-winter are presented. During this period copepodite Stages CIV and CV and adult females of $C$. acutus underwent an ontogenetic downward migration, which in CIV seemed to be delayed until early winter if moderate biomass of phytoplankton was sustained in the upper water layers. The descent of CV and CVI was close to completion already by June while CIV continued to sink down slowly during the winter. By mid-winter, sexual differentiation in $C V$, maturation of males, and the onset of female maturation were observed for $C$. acutus. Males of $C$. acutus maintained rather restricted vertical distribution centered in the core of the Warm Deep Water. C propinquus showed no indication of regular ontogenetic migration, but did show some seasonal changes in the vertical distroution of particular stages with a strong geographical variability. The bulk of the overwintenng $C$. propinquus population in the Weddell Gyre consisted of CIII and did not leave the Winter Water. The maturation of males and females in C. propinquus began in winter as well. $R$. gigas underwent a downward migration, which was only detected in those parts of the Weddell Gyre where some recruitment of that species took place, i.e. at the Weddell Front and in the Maud Rise area. Although sexual differentiation in CV was in progress in winter, the onset of maturation of both males and females in $R$. gigas appeared to be delayed until at least the end of winter
\end{abstract}

KEY WORDS: Copepods A Antarctica $\cdot$ Migrations $\cdot$ Maturation $\cdot$ Sex ratio

\section{INTRODUCTION}

The large dominant Antarctic herbivorous copepods Calanoides acutus, Calanus propinquus, and Rhincalanus gigas have long life cycles during which they encounter rather short periods of favourable food conditions and longer periods of food deprivation. Recent studies on the population dynamics, physiology and vertical distribution of $C$. acutus, $C$. propinquus, and $R$. gigas indicated that these species exhibit different life strategies. Their response to food limitation in winter

•E-mail: arthro@glasnet.ru may include storing of energy-rich compounds during the productive period, a delay in development of the overwintering population, lowering of metabolic rates, ceasing of feeding, and seasonal and/or ontogenetic vertical migrations (Bathmann et al. 1993, Drits et al. 1993, Kattner et al. 1994, Pasternak et al. 1994, Schnack-Schiel \& Hagen 1994, Hagen \& SchnackSchiel 1996).

The current concept of ontogenetic migrations of Calanoides acutus, Calanus propinquus and Rhincalanus gigas is based on numerous observations on vertical distribution obtained almost exclusively during autumn and spring (Voronina 1984, SchnackSchiel et al. 1991, Marin \& Schnack-Schiel 1993). The only winter data covering considerable depths were 
reported by Vladimirskaya (1978), Atkinson (1991) and Bathmann et al. (1993) for September-October and by Schnack-Schiel \& Hagen (1995) for August The data available do not answer the questions of whether the vertical distribution remains stable throughout the winter and what the vertical distribution of the particular developmental stages is.

Studies on physiology and population dynamics of herbivorous copepods in the polar environments show that winter is the season of a reduced metabolic activity and arrested development in many of them (Conover 1965, Hirche 1983, Conover \& Huntley 1991, Bathmann et al. 1993, Pasternak et al. 1994, SchnackSchiel \& Hagen 1995). At the same time, it is the major period of the preparation for reproduction in large cold-water herbivorous copepods. Throughout the winter, sexual differentiation and gonad maturation take place in copepodite Stage $V$ (CV) and adults of the boreal and arctic Calanus species (Maclellan 1967, Tande \& Hopkins 1981, Hirche 1997, Kosobokova in press), apparently fueled by stored energy resources (Hagen \& Schnack-Schiel 1996). Seasonal variation in the occurrence of males in C. acutus and C. propinquus Vladimirskaya 1978, Marin 1988, SchnackSchiel et al. 1991, Bathmann et al. 1993, Kosobokova 1994a) also suggests that sexual differentiation in these species takes place mostly during winter. However, no data on the onset of gonad maturation in these species are available to date.

In this paper we present data on abundance, stage composition and vertical distribution, sex ratio, and maturity states of Calanoides acutus, Calanus propinquus and Rhincalanus gigas obtained during the Winter Weddell Gyre Study 1992 on RV 'Polarstern' in early to mid-winter (Lemke 1994). Using these data, we consider the winter phases of ontogenetic migration and the gonad development in these 3 species in an attempt to fill a seasonal gap in their life cycle studies.

\section{MATERIAL AND METHODS}

Zooplankton were collected during the expedition Antarktis X/4 of RV 'Polarstern' on a longitudinal transect along the Greenwich meridian (Greenwich transect), a transect from the central part of the Weddell Gyre to the South Orkney Islands (West transect), and a short latitudinal transect crossing a deep canal between the shelves of the South Orkney Islands and Clarence Island (South Orkney transect) and at Stn 612 off Kapp Norwegia. The latter transect was continued to the north, towards the Weddell-Scotia Confluence (Fig 1). Sampling was carried out using a Multinet (Hydrobios, Kiel; $0.25 \mathrm{~m}^{2}$ mouth opening) and a Bongo net $\left(0.28 \mathrm{~m}^{2}\right.$ mouth opening), both having $100 \mu \mathrm{m}$ mesh size. Usually, 5 depth layers were chosen for Multinet sampling based on the thermohaline structure of the water column in which the Winter Water $(80$ to $120 \mathrm{~m}$ ), the layer of the permanent thermocline and the Warm Deep Water (WDW) above and below the temperature maximum were obligatorily sampled.

Zooplankton sampling on the Greenwich transect was carried out during the onset of winter between 4 and 18 June 1992. Multinet tows were conducted at 10 stations mostly down to $1000 \mathrm{~m}$ (Stns 589 and 598 to $2000 \mathrm{~m}$ ). A Bongo net was towed vertically at 6 stations from $500 \mathrm{~m}$ to the surface (Fig. 1).

The following hydrographic regimes were investigated: the Polar Front (Stn 571), the southernmost core of the Antarctic Circumpolar Current (ACC) (Stn 575), the Weddell Front (Gouretski \& Danilov 1993, Spiridonov et al. 1996) at Stns 576 to 577 , the Weddell Gyre interior with the Cold and the Warm Regimes, and the Coastal Current south of the Continental Water Boundary (Spiridonov et al. 1996). Within the Warm Regime, the warm core features bounding the Maud Rise are worth noting. At Stn 612 samples were taken in the typical Coastal Current regime on June 30.

On the West transect, sampling was performed down to $1000 \mathrm{~m}$ or to the bottom between 14 and 21 July at 2 Multinet and 4 Bongo net stations (Stns 625 to 635).

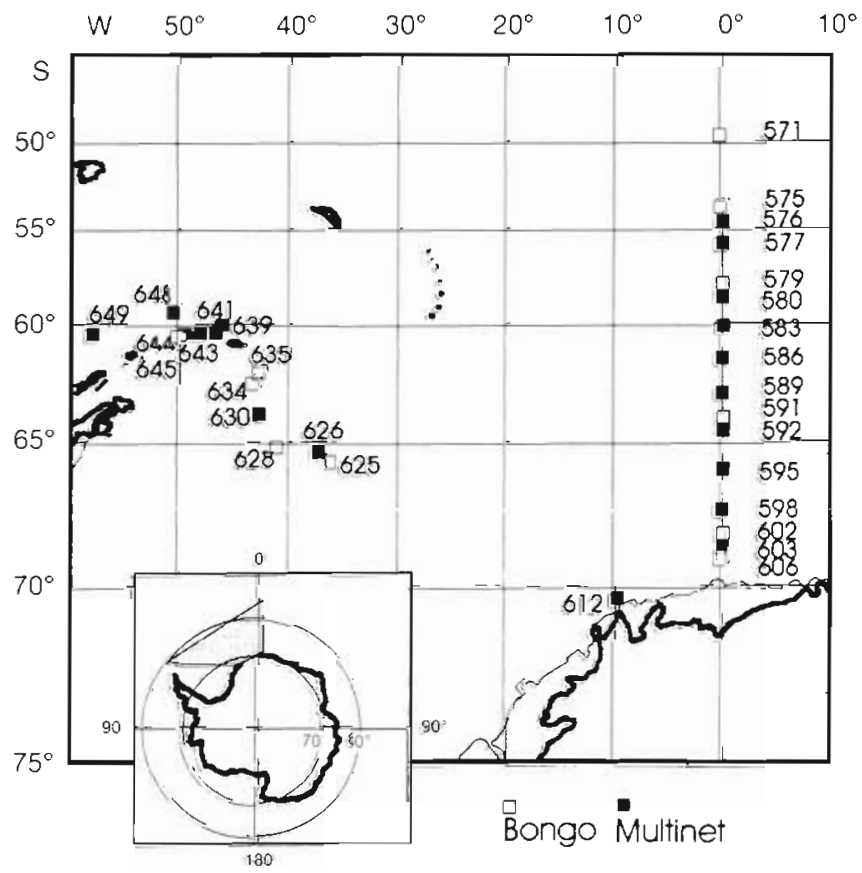

Fig. 1. Stations at which zooplankton sampling was performed in the Weddell Sea and adjacent areas during the Winter Weddell Gyre Study 1992 (Antarktis X/4) in JuneJuly 1992 
This transect covered a typical regime of the Weddell Sea interior with a slight signal of WDW recirculating in the Weddell Gyre, and (at Stn 635) the shelf of South Orkney Islands (Schröder et al. 1994).

The South Orkney transect included 5 Multinet stations and 1 Bongo net station. Sampling was performed down to the bottom or to $1500 \mathrm{~m}$. In the eastern part of this transect (Stns 639, 640), an outflow of the WDW out of the Weddell Sea was observed (Schröder et al. 1994). In the west (Stns 644, 645, 648), the water column was quite vertically homogenous, which indicated conditions typical of the Weddell-Scotia Confluence (Gordon 1967, Whithworth et al. 1994). Additionally, Stn 649 was taken in the ACC waters north of South Shetland Islands.

Net samples were preserved in $4 \%$ borax-buffered formalin; they were examined under a stereo-microscope. All copepodite stages of Calanoides acutus, Calanus propinquus, and Rhincalanus gigas were counted.

The median depth and the first and the third quartile depth of occurrence (Moore 1949) for all developmental stages in the upper $1000 \mathrm{~m}$ of the water column were calculated in order to show $50 \%$-cores of each hemipopulation, i.e. the portion of a species population at the same developmental stage (Beklemishev 1969, Voronina 1974).

All CVs, adult females and males of the 3 species were sorted out from a total sample (for small samples) or a random subsample $(1 / 3$ to $1 / 4$ of the total sample, i.e. 40 to 100 specimens, for large samples) and stained in a $2 \%$ borax carmin solution according to Tande \& Hopkins (1981). Then, copepods were examined under a stereomicroscope to separate sex in CVs and to score states of maturity in adult females. A simple classification scheme for female gonad maturity in Calanoides acutus and Calanus propinquus based on the presence of oocytes in diverticula and oviducts and the size of ovaries and oocytes was derived from direct observations of preserved specimens collected throughout the year (Kosobokova 1994a, b): I, immature (ovary small, diverticula and oviducts empty); II, semi-mature (ovary enlarged, diverticula with 1 row of small oocytes); III, semi-mature (diverticula with several rows of small oocytes, more than 1 row of small oocytes in oviducts); IV, mature (diverticula with several rows of large oocytes, pouches of large oocytes in oviducts): V, semispent (diverticula and oviducts with sparse irregularly distributed oocytes); VI, spent (no oocytes present, diverticula and oviducts empty, ovary large with empty space in the front part and homogeneous mass in the posterior part).

The genital morphology of the Eucalanidae is somewhat different from that of the Calanidae (Ommaney 1936, Smith \& Lane 1991), but will not be discussed here as all female Rhincalaus gigas were in the earliest stage of maturation.

In all specimens examined for sex separation and maturity states, the prosome length was measured under a stereomicroscope from the tip of the cephalosome to the distal lateral end of the last thoracic segment with an accuracy of $0.01 \mu \mathrm{m}$.

\section{RESULTS}

\section{Horizontal distribution and stage composition of copepod populations}

Geographical variation in abundance of Calanoides acutus, Calanus propinquus and Rhincalanus gigas shows certain characteristic distribution patterns. In all 3 species we observed the maximum abundance in the southern $\mathrm{ACC}$ in the eastern Atlantic and the minimum at the Weddell Front (Fig. 2A). Similarly, very low numbers (less than 1000 ind $\mathrm{m}^{-2}$ in the upper $1000 \mathrm{~m}$ ) were observed at the South Orkney shelf and in the WeddellScotia Confluence. In the Weddell Gyre interior and in the Coastal Current $C$. acutus and $C$. propinquus reached moderate to high abundance while $R$. gigas was poorly represented in most of that area (Fig. 2A).

In Calanoides acutus, CIV was a dominant stage at most stations in the Weddell Gyre in June. The dominance shifted to $\mathrm{CV}$ in the north (ACC) and at some stations between the Maud Rise and the Coastal Current zone (Fig. 2B). CIII comprised the bulk of the population in the Coastal Current (Fig. 2B) but at other stations it was rather scarce. In July $C V$ became the dominant stage both in the Weddell Gyre interior and near the South Orkneys and in the Weddell-Scotia Confluence.

Calanus propinquus was represented mainly by $\mathrm{CV}$ in the ACC waters in June; in the Weddell Front, dominance shifted to CIV; however, further south in the Weddell Gyre, in the Coastal Current, CIII became distinctly dominant (Fig. 2C). In the zone of low abundance at the South Orkney shelf and near the WeddellScotia Confluence, stage distribution was bimodal with CIII and CV dominating.

In Rhincalanus gigas all copepodite stages were present throughout the Greenwich transect (Fig. 3A to D), nauplii occurred at the Weddell Front and in the Maud Rise area (Fig. 3A, C). At most stations (except the Maud Rise area, Fig. 3C) stage composition was distinctly bimodal. Usually CII and either CV or CVI dominated the population. Along the West transect nauplii were absent and CI to CIII were poorly represented (Fig. 3F). North of the South Orkney Islands stage composition was also bimodal, with CII and CVI being the dominant stages (Fig. 3E). 


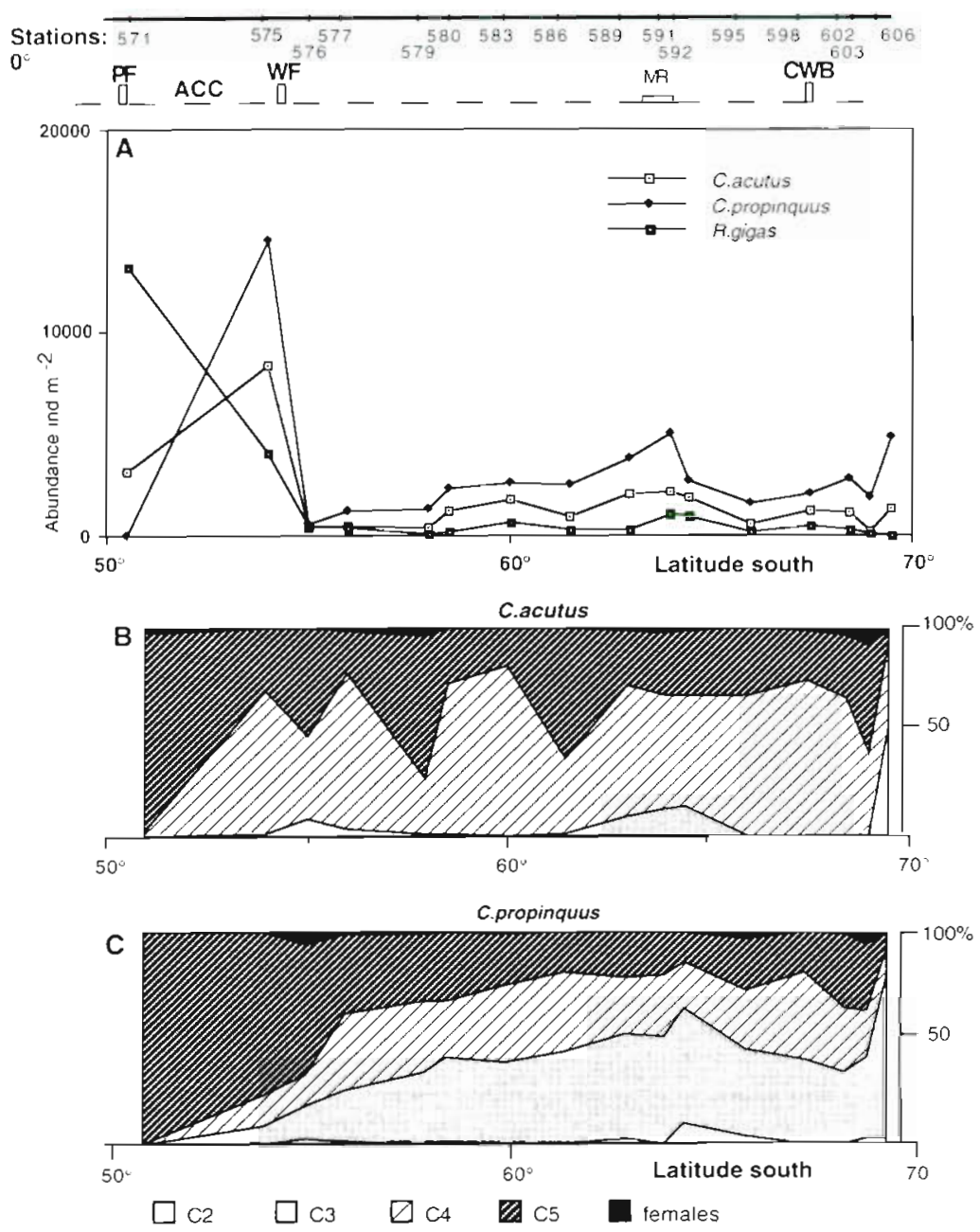

Fig. 2. Abundance of Calanoides acutus, Calanus propinquus, and Rhincalanus gigas $(\mathrm{A})$ and stage composition of $C$. acutus $(\mathrm{B})$ and $C$. propinquus (C) populations along the Greenwich transect in the upper 0 to $500 \mathrm{~m}$ water layer. PF: Polar Front; ACC: Antarctic Circumpolar Current; WF: Weddell Front; MR: Maud Rise; CWB: Continental Water Boundary. C2 to C5: copepodite stages male, Table 1). Male-to-female ratio in adults varied from 0.6 to 19.8 , although adult males were more abundant than females at most stations (Table 1).

Throughout the Greenwich transect. Calanoides acutus adult females were immature (Table 1); however, the gonads of both adult and CV females were seemingly larger in the deepest layers. Likewise, in the western Weddell Gyre interior, no indication of gonad maturation was observed. At the most northern stations of the South Orkney transect at the end of July, females appeared to start maturation: states II and III (semimature) comprised 20 to $30 \%$ of females (Table 1). The commencement of maturation was associated with the high male-to-female ratio (1.3 to 1.5 ). In contrast, at the ACC Stn 649 all females were immature, despite extremely high sex ratio of ca 20 males per female (Table 1).

In Table 2 mean prosome lengths of Calanoides acutus CVs separated by sex and of adult females and males are shown. The mean prosome length of $\mathrm{CV}$ females was larger than that of $\mathrm{CV}$ males; the difference was statistically significant (Student's t-test, $\mathrm{p}<0.001$ ). The prosome length of adult females was larger than that of CV females indicating a considerable increase of the body length when molting to adult state. In contrast, the mean prosome length of adult males was less compared to that of CV males (Student's $t$-test, $p<0.001$ ).

\section{Calanus propinquus}

\section{Sex ratio and gonad development in $\mathrm{CV}$ and females}

\section{Calanoides acutus}

In June almost all CVs in the studied depths had undifferentiated gonads. The CVs with a distinct male gonad were found at the Weddell Front and in the Coastal Current Zone (Table 1). Adult females occurred occasionally, mostly in the Weddell Gyre, while adult males were not observed at all (Table 1).

In July the proportion of males in CV varied from 10 to $49 \%$. Adult females were more abundant than in June, comprising 39 to $62 \%$ of the population in the northern Weddell Gyre (Table 1). On the South Orkney transect, CV males were found at each station, however their proportion did not exceed 10 to $23 \%$ ( 0.1 to 0.3 males per fe-
Sexual differentiation in CV was observed mostly in the northern part of the Weddell Gyre (Table 1 ). Sex ratio varied between 0.02 and 0.16 males per female, where males were present (Table 1). Adult males were not found at any of the stations except Stn 639, where they comprised nearly one-third of CVI (Table 1). Adult females were immature at most stations except Stn 639 (the area of the South Orkney polynya, see Haas et al. 1992) where they began to mature in late July (Tabie 1).

Since males in Calanus propinquus were sparse, size differences were only examined for females. CVI females were significantly larger than $\mathrm{CV}$ females (Table 2; Student's $t$-test, $p<0.01$ ). 


\section{Rhincalanus gigas}

CVs were clearly differentiated by sex: sex ratio varied from 0.7 to 2.7 males per female (Table 1 ). Only a few adult males were found, in the Weddell Front and in the ACC waters (Stn 649). All adult females were immature (Table 1).

\section{Vertical distribution of copepod populations}

\section{Calanoides acutus}

At the Weddell Front in early June, CIII distribution was almost always restricted to the Winter Water, while CIV inhabited deeper layers from the thermocline to the upper WDW, down to the maximum temperature layer. CV and adult females were confined to the water layers below $500 \mathrm{~m}$ (Fig. 4). A similar situation of markedly increasing depth of occurrence in advanced stages was observed in the Warm Regime waters around Maud Rise and further south in midJune (Fig. 4, Table 3). Sampling to $2000 \mathrm{~m}$ depth at Stns 589 and 598 revealed deepening of the CIV hemipopulation from north to south, which was not seen in the upper $1000 \mathrm{~m}$ water column (Fig. 5A, B). Adult females inhabited the deepest layers: ca $50 \%$ of their hemipopulation were found below $1000 \mathrm{~m}$. In the Coastal Current zone, the density of all stages increased with depth and the bulk of the population was concentrated below $1000 \mathrm{~m}$. CV was the most deep-living stage there (Fig. 5C).

In the southernmost part of the West transect in July, more advanced stages still occupied greater median depths (Table 3). Further to the north this pattern changed. South and north of the South Orkney Islands adults inhabited less deep layers than, at least, CIV. At the northernmost stations in late July CIV clearly became the most deep-living stage (Fig. 6A, B, Table 3).

Vertical distribution of males and females differed considerably in both $\mathrm{CV}$ and adults. In the Weddell Front in mid-June, CV males were confined to the 500 to $1000 \mathrm{~m}$ layer while $\mathrm{CV}$ females had a wider vertical distribution (Fig. 7). At the western Weddell Gyre in July, males comprised up to one third of the total abundance of CVs between 500 and 750 (800) m, while females distinctly dominated below $750 \mathrm{~m}$ (Fig. 7). Adult females were usually more numerous than adult males in the layers deeper than $1000 \mathrm{~m}$. Between 500 and 800 (or at some stations 1000 ) $\mathrm{m}$, males comprised 50 to $65 \%$ of adults (Fig. 7). At ACC Stn 649, both CV and CVI males were concentrated in a narrow layer (400 to $600 \mathrm{~m}$ ), while females were widely distributed in the vertical (Fig. 6C).
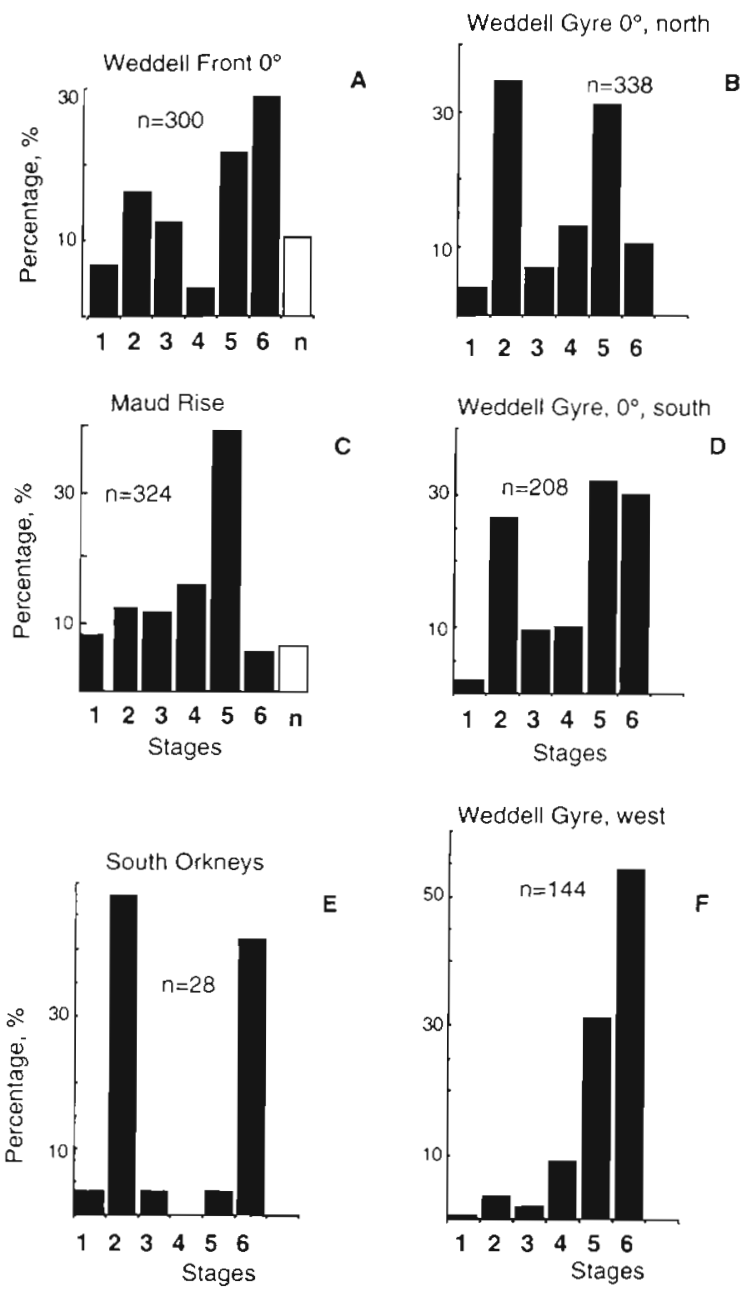

Fig. 3. Developmental stage composition of Rhincalanus gigas at: (A) the Weddell Front at the Greenwich meridian, Stns 576 and 577; (B) the northern Weddell Gyre at the Greenwich meridian, Stns 579 to 589; (C) the Maud Rise area, Stns 591 and 592; (D) the Weddell Gyre south of Maud Rise; (E) the South Orkney transect; and (F) the West transect. 1 to 6, copepodite stages; $\mathbf{n}$ : nauplii. $\mathbf{n}=$ total number of individuals

\section{Calanus propinquus}

In the Weddell Gyre, ca $90 \%$ of CIII to CV were concentrated in the Winter Water (see also Spiridonov et al. 1996). Nevertheless, the older stages, especially adult females, tended to occur deeper than young copepodites, often below $500 \mathrm{~m}$ (Fig. 8B). This pattern was dominant throughout the area studied, although the most northern and the most southern stations showed a somewhat different situation. In the Weddell Front in early June, CIII was the most abundant in the Winter Water, while CIV reached higher density in the thermocline layer. In turn, CV was found deeper than CIV (Fig. 8A). In the poorly stratified Coastal Current 
Table 1 Sex ratio in copepodite Stage V (CV) and adults (CVI) and maturity states of females in Calanoides acutus, Calanus propinquus, and Rhincalanus gigas in 1992. GT: Greenwich transect; WT. West transect; SOT: South Orkney transect; ACC:

Antarctic Circumpolar Current. NE: not examined. 'Immature' includes maturity states I and VI

\begin{tabular}{|c|c|c|c|c|c|c|c|c|c|c|c|}
\hline Transect & $\operatorname{Sin}$ & Date & Depth $(\mathrm{m})$ & \multicolumn{2}{|c|}{$\begin{array}{l}\text { No. of ind. } \\
\mathrm{CV}_{8} \mathrm{CV}_{\circ}\end{array}$} & \multirow[t]{2}{*}{$\begin{array}{l}\text { Sex ratio } \\
\mathrm{CV}_{\sigma}: \mathrm{CV}_{8}\end{array}$} & \multicolumn{2}{|c|}{$\begin{array}{l}\text { No. of ind. } \\
\mathrm{CVI}_{\odot} \mathrm{CVI}_{\circ}\end{array}$} & \multirow[t]{2}{*}{$\begin{array}{l}\text { Sex ratio } \\
\mathrm{CVI}_{\sigma^{\prime}}: \mathrm{CVI}_{Q}\end{array}$} & \multicolumn{2}{|c|}{$\begin{array}{l}\text { Female maturty state } \\
\text { State Proportion }(\%\end{array}$} \\
\hline \multicolumn{10}{|c|}{ Calanoides acutus } & & \\
\hline GT & 577 & 9 Jun & 1000 & 53 & 6 & 0.1 & 5 & 0 & 0 & Immature & 100 \\
\hline GT & 586 & $11 \mathrm{Jun}$ & 1000 & 150 & 0 & 0 & 2 & 0 & 0 & Immature & 100 \\
\hline GT & 598 & 16 Jun & 2000 & 143 & 0 & 0 & 28 & 0 & 0 & Immature & 100 \\
\hline WT & 612 & 30 Jun & 1360 & 31 & 2 & 0.06 & 12 & 0 & 0 & Immature & 100 \\
\hline WT & 630 & $19 \mathrm{Jul}$ & 1000 & 154 & 76 & 0.5 & 67 & 7 & 0.1 & Immature & 100 \\
\hline SOT & 639 & $26 \mathrm{Jul}$ & 1100 & 43 & 12 & 0.3 & 29 & 18 & 0.6 & Immature & 100 \\
\hline SOT & 641 & $27 \mathrm{Jul}$ & 1500 & 36 & 7 & 0.2 & 44 & 27 & 0.6 & Immature & 100 \\
\hline SOT & 645 & $28 \mathrm{Jul}$ & 1000 & 34 & 10 & 0.3 & 39 & 52 & 1.3 & $\begin{array}{c}\text { Immature } \\
\text { II-III }\end{array}$ & $\begin{array}{l}70 \\
30\end{array}$ \\
\hline SOT & 648 & $29 \mathrm{Jul}$ & 1500 & 62 & 7 & 0.1 & 41 & 63 & 1.5 & $\begin{array}{c}\text { Immature } \\
\text { II-III }\end{array}$ & $\begin{array}{l}80 \\
20\end{array}$ \\
\hline $\mathrm{ACC}$ & 649 & $31 \mathrm{Jul}$ & 1000 & 47 & 45 & 1.0 & 4 & 39 & 19.8 & Immature & 100 \\
\hline \multicolumn{12}{|c|}{ Calanus propinquus } \\
\hline GT & 577 & 9 Jun & 1000 & 96 & 3 & 0.03 & 2 & 0 & 0 & I & 100 \\
\hline GT & 586 & 11 Jun & 1000 & 18 & 0 & 0 & 0 & 0 & NE & $N E$ & $\mathrm{NE}$ \\
\hline GT & 598 & $16 \mathrm{Jun}$ & 2000 & 1 & 0 & 0 & 2 & 0 & 0 & I & 100 \\
\hline WT & 612 & $30 \mathrm{Jun}$ & 1360 & 11 & 0 & 0 & 0 & 0 & $\mathrm{NE}$ & $\mathrm{NE}$ & $\mathrm{NE}$ \\
\hline WT & 630 & $19 \mathrm{Jul}$ & 1000 & 48 & 1 & 0.02 & 12 & 0 & 0 & $\mathrm{I}$ & 100 \\
\hline SOT & 639 & $26 \mathrm{Jul}$ & 1100 & 31 & 5 & 0.16 & 18 & 8 & 0.44 & II & 100 \\
\hline SOT & 641 & $27 \mathrm{Jul}$ & 1500 & 7 & 0 & 0 & 5 & 0 & 0 & I & 100 \\
\hline SOT & 645 & $28 \mathrm{Jul}$ & 1000 & 2 & 1 & 0.5 & 2 & 0 & 0 & 1 & 1.00 \\
\hline SOT & 648 & $29 \mathrm{Jul}$ & 1500 & 3 & 0 & 0 & 3 & 0 & 0 & I & 100 \\
\hline \multicolumn{12}{|c|}{ Rhincalanas gigas } \\
\hline GT & 577 & 9 Jun & 1000 & 3 & 8 & 2.7 & 13 & 1 & 0.08 & Immature & 100 \\
\hline GT & 586 & $11 \mathrm{Jun}$ & 1000 & 17 & 12 & 0.7 & 12 & 0 & 0 & Immature & 100 \\
\hline GT & 598 & $16 \mathrm{Jun}$ & 2000 & 5 & 6 & 1.2 & 9 & 0 & 0 & Immature & 100 \\
\hline WT, SOT & $630-648$ & 19 to $29 \mathrm{Jul}$ & See above & 3 & 8 & 2.7 & 39 & 0 & 0 & Immature & 100 \\
\hline $\mathrm{ACC}$ & 649 & $31 \mathrm{Jul}$ & 1000 & 47 & 35 & 0.7 & 4 & 1 & 0.02 & Immature & 100 \\
\hline
\end{tabular}

waters all stages were abundant throughout the entire water column down to $1300 \mathrm{~m}$. However, CIII had a density maximum in the upper layers, while CIV and CV were rather scarce there (Fig. 8C). In the South Orkney coastal polynya (Haas et al. 1992) the bulk of all stages including adult males was confined to the Winter Water, although CIII penetrated down to considerable depth (Fig. 8D)

\section{Rhincalanus gigas}

In general, near the Weddell Front the older the stage was, the deeper it was found: CI and CII were restricted to the Winter Water, while adults occurred in the core of the WDW (Fig. 9). This regular pattern was also observed in the Warm Regime waters in the Maud Rise area. However, at most stations in the Weddell Gyre all stages mainly inhabited the WDW. Regularities in vertical distribution of particular stages were not observed: younger stages sometimes occurred deeper than older ones (Fig. 9). Nevertheless, in this region CI also inhabited more shallow depths than other stages, while the median depth of occurrence for adults was always the deepest (between 400 and $600 \mathrm{~m}$ ). Rhincalanus gigas was virtually absent below $1000 \mathrm{~m}$.

Table 2. Mean prosome length (MPL) of males and females in $\mathrm{CV}$ and adults of Calanoides acutus and Calanus propinquus. SD: standard deviation: CL: confidence limits

\begin{tabular}{|lrrrl|}
\hline Species, stage, sex & $\begin{array}{c}\text { No. of } \\
\text { ind. }\end{array}$ & $\begin{array}{c}\text { MPL } \\
(\mathrm{mm})\end{array}$ & SD & $\begin{array}{c}\mathrm{CL} \\
(0.99)\end{array}$ \\
\hline Calanoides acutus & & & & \\
CV, females & 150 & 3.86 & 0.16 & 0.026 \\
CV, males & 115 & 3.68 & 0.169 & 0.03 \\
CVI, females & 181 & 4.36 & 0.216 & 0.031 \\
CVI, males & 143 & 3.54 & 0.174 & 0.028 \\
Calanus propinquus & & & & \\
CV, females & 177 & 3.45 & 0.179 & 0.026 \\
CVI, females & 33 & 4.29 & 0.134 & 0.046 \\
\hline
\end{tabular}


Fig. 4. Vertical distribution of temperature $\left({ }^{\circ} \mathrm{C}\right)$ and characteristics of the vertical distribution of particular copepodite stages of Calanoides acutus sampled to $1000 \mathrm{~m}$ depth along the Greenwich transect. Vertical lines (1) show the range of occurrence, horizontal bars (2) mark the median depth of occurrence, and rectangles (3) cover the range centered around the median depth where a core $150 \%$ of a hemipopulation) is concentrated. $\mathrm{C} 3$ to $\mathrm{C} 6$ copepodite stages

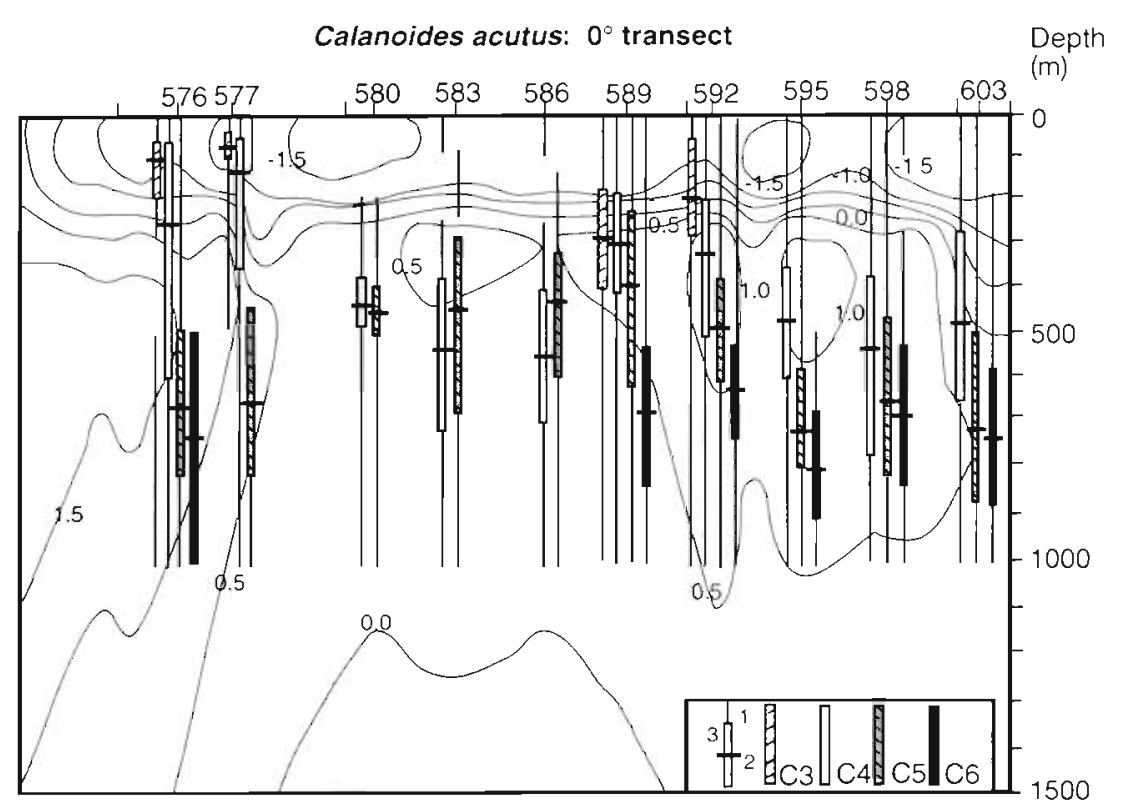

\section{DISCUSSION}

\section{Composition of the overwintering populations of large calanoids in the Weddell Gyre}

In most areas of the Weddell Gyre, the dominant overwintering stage of Calanoides acutus was CIV, similar to earlier observations (Bathmann et al. 1993). We believe this stage along with CIII belongs to the summer generation of the current year. On the other hand, in some areas of the Weddell Gyre CV dominated the population in winter (Fig. 2). These areas may be characterized by longer seasonal ice cover compared to the waters north and east of the Maud Rise (Zwally et al. 1983, Haas et al. 1992, Parkinson 1993). It is doubtful that most individuals of a new generation in these areas are able to reach CV during only one short summer season. We suggest that at least a part of C. acutus CVs and probably most of CVIs found in winter in the Weddell Gyre are older than 1 yr, thus overwintering for the second time. Pasternak et al. (1994) came to a similar conclusion based on data on physiology and lipid content of CVs and CVIs at the end of summer.

Both our study and that of Bathmann et al. (1993) indicate that CIII is the dominant overwintering stage in the Weddell Gyre population of Calanus propinquus, most likely representing a recently recruited generation. On the other hand, at some stations in the northwestern Weddell Sea we observed a bimodal stage composition with CV and/or CVI being the second dominant stage(s) in winter. Such a stage composi- tion fits well the hypothesis of a 2 -yr life cycle of $C$. propinquus at least in some parts of the area in which it occurrs (Drits et al. 1993, Kurbjeweit 1993).

Bimodal stage composition of the Rhincalanus gigas population observed during this study supports the hypothesis of the more than 1-yr life cycle proposed in the most recent studies (Marin 1988, Atkinson 1991, Bathmann et al. 1993, Pasternak et al. 1994). However, all copepodite stages were found in winter indicating their ability to survive long periods of very low food availability.

Table 3. Median depth of occurrence $(\mathrm{m})$ of Calanoides acutus CIV, CV and CVI (adults) in the upper $1000 \mathrm{~m}$ water layer in 1992. NEWG: northeastern Weddell Gyre; SEWG: southeastern Weddell Gyre; WWI: western Weddell Gyre interior; SO: South Orkney area; WSC: Weddell-Scotia Confluence. NC: not calculated

\begin{tabular}{|lcllll|}
\hline \multirow{2}{*}{ Area } & \multirow{2}{*}{ Stn } & Date & \multicolumn{3}{c|}{ Copepodite stages } \\
& & & IV & V & VI \\
\hline NEWG & 580 & 10 Jun & 460 & 450 & NC \\
NEWG & 583 & 11 Jun & 540 & 470 & NC \\
NEWG & 586 & 12 Jun & 550 & 440 & NC \\
SEWG & 595 & 15 Jun & 450 & 750 & 820 \\
SEWG & 598 & 16 Jun & 530 & 660 & 690 \\
SEWG & 603 & 17 Jun & 475 & 730 & 750 \\
WWI & 626 & 16 Jul & 460 & 600 & 690 \\
WWI & 630 & 19 Jul & 570 & 565 & 720 \\
SO & 639 & 26 Jul & 710 & 720 & 690 \\
WSC & 641 & 27 Jul & 700 & 660 & 705 \\
WSC & 645 & 28 Jul & 825 & 790 & 810 \\
WSC & 649 & 29 Jul & 750 & 810 & 720 \\
& & & & & \\
\hline
\end{tabular}




\section{Late autumn to mid-winter ontogenetic migrations}

Voronina $(1972,1974,1984)$ presented a scheme intended to describe the ontogenetic migration pattern in the 3 species studied here. She assumed that all developmental stages are concentrated in the Antarctic surface water during most of summer, while during late summer and autumn they shift to greater depth, with advanced stages tending to occur deeper than younger ones, and disperse in the deeper water column. When upward seasonal migration starts, older stages are found closer to the surface. Later investigations (Atkinson 1991, Huntley \& Escritor 1991, Schnack-Schiel et al. 1991, Bathmann et al. 1993, Voronina \& Kolosova 1993. Schnack-Schiel \& Hagen.1994) disputed the generality of Voronina's scheme, but showed that it is in principle correct for Calanoides acutus.

The present data indicate, however, unexpected geographical variation in the timing of seasonal descent of Calanoides acutus. The more advanced phase of descent of its population was observed in the Weddell Gyre interior, compared to the vertical distribution of the populations in the Weddell Front and the Maud Rise area.

Although factors inducing the rest-
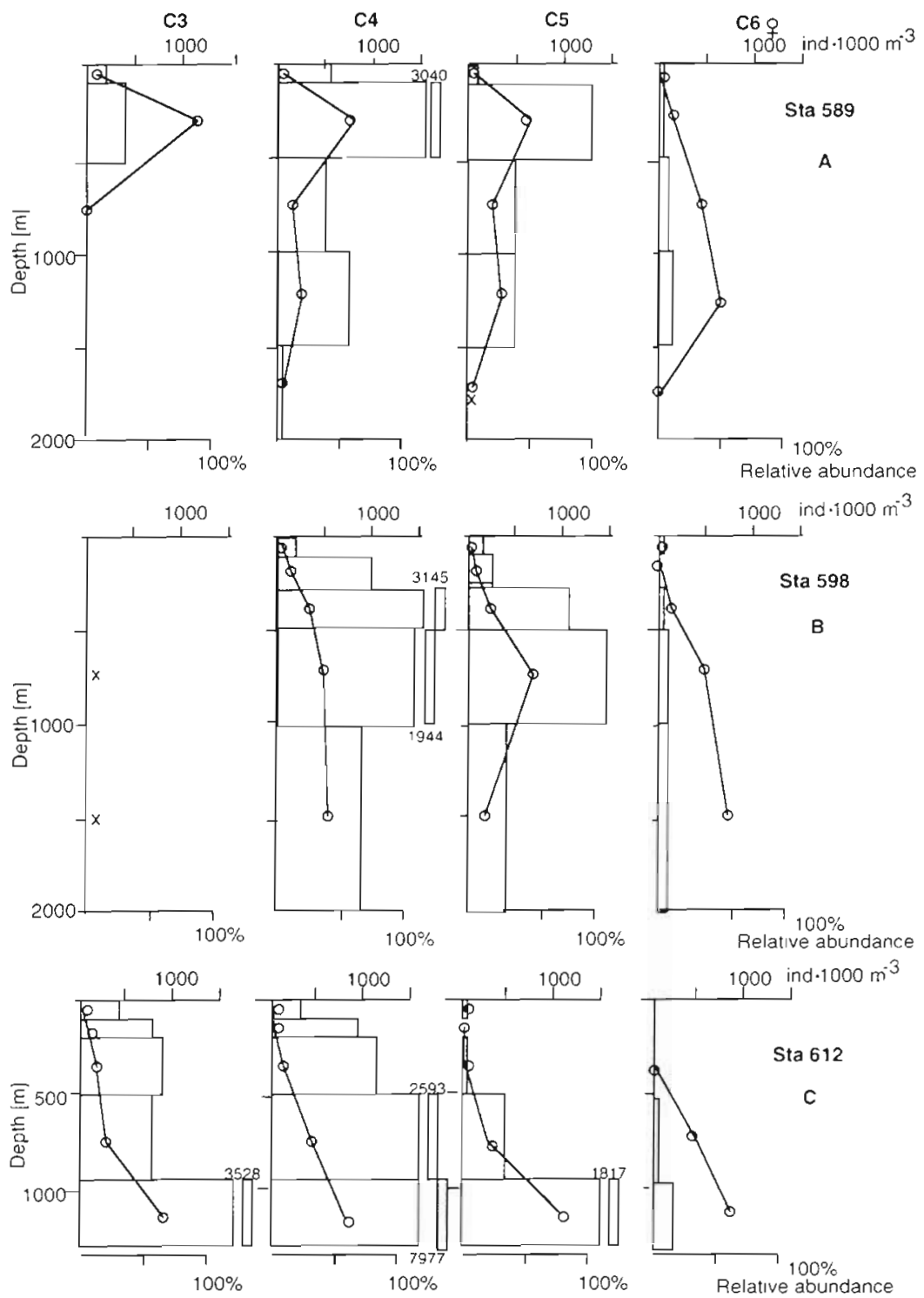

Fig. 5. Examples of the vertical distribution of Calanoides acutus at particular stations in the Weddell Gyre (A, B) and in the Coastal Current (C). Histograms show absolute numbers; line graphs represent proportions of hemipopulations inhabitung particular layers; $x$ : very low abundance $\left(<1 \mathrm{ind} \cdot 1000 \mathrm{~m}^{-3}\right)$ of a stage ing state and the onset of descent in the Calanidae are largely unknown, the role of decreasing photoperiod is quite possible (Grigg \& Bardwell 1982, Miller et al. 1991). However, regional variations in the Calanoides acutus CIV descent in the area under study cannot be unambiguously explained by decreasing daylight duration with increasing latitude. Rather, specific regional characteristics of copepod populations and the whole plankton communities related to hydrography must be taken into account.

The Weddell Front and the Maud Rise area are the areas of late spawning in several zooplankton species, including Calanoides acutus; some reasons for this are discussed by Spiridonov et al. (1996). Thus the CIII and CIV in the Weddell Front and in the Maud Rise area that had not yet descended could be the recruits from late spawning which continued feeding on moderate phytoplankton biomass available in these areas until the onset of winter (Spiridonov et al. 1996). CIV in the Weddell Gyre interior could have originated from the usual summer spawning period and therefore started descent much earlier.

When comparing the available early winter data for the upper $2000 \mathrm{~m}$ with those for the late winter (Bathmann et al. 1993), it appears that the core of CV in both seasons occurred generally between 500 and $1000 \mathrm{~m}$. These data suggest the descent of $\mathrm{CV}$ and CVI already is close to completion by June, while CIV seems to continue to sink slowly during the winter. The stations 

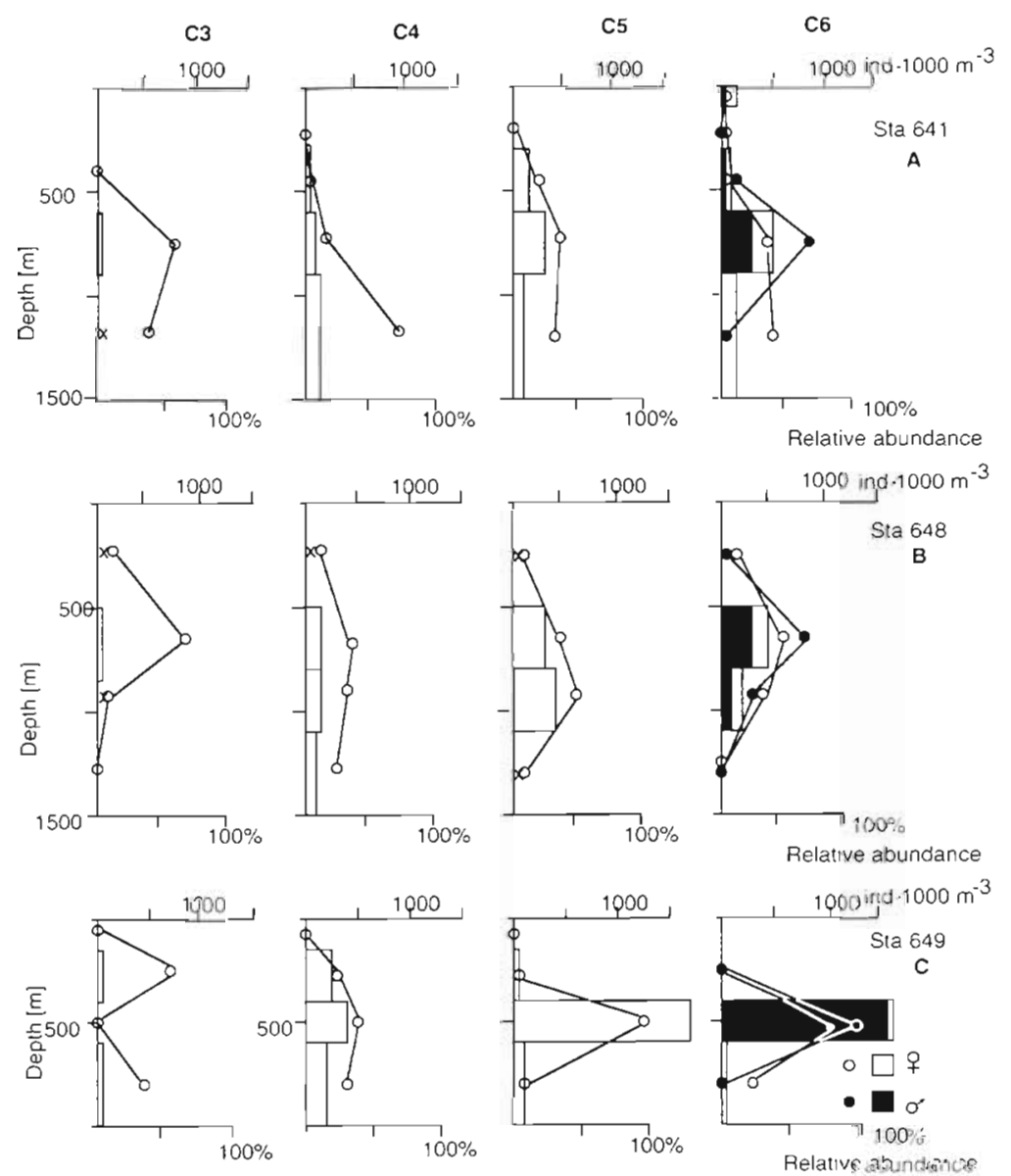

Fig. 6. Examples of the vertical distribution of Calanoides acutus at particular stations in the Weddell-Scotia Confluence (A, Bj) and in the Antarctic Circumpolar Current (C). Conventions as in Fig. 5 males usually belong to the most lipidrich fraction of CV and CVI with rather narrow individual variability of body size and lipid content (Kattner et al. 1994, Schnack-Schiel \& Hagen 1994, Kosobokova unpubl.). They appear to have a somewhat lower and rather constant density compared to most pre-adult and adult females, which are larger in size (Table 2) and have a variable amount of lipids (Hagen 1988, Kosobokova et al. 1993, Pasternak et al. 1994, SchnackSchiel \& Hagen 1994). Thus sinking of $\mathrm{CV}$ males is probably balanced by an increase of water viscosity in a rather restricted layer of the WDW core, while heavier females continue to disperse in the water column.

The vertical distribution of Calanus propinquus also varied between the major hydrographic regimes during our observations. In the Weddell Front there were some indications of seasonal changes in vertical distribution of particular stages, i.e. part of the CIVs and CVs moved from the upper mixed layer to the permanent thermocline layer and to the upper WDW. A similar situation was also observed in late summer and autumn in the modified ACC waters in the eastern Atlantic (Voronina 1974) and in the mar- in the northwestern Weddell Sea in late July showed some further steps of this process: CIV were rather evenly distributed below $500 \mathrm{~m}$ with a core lying well below that of $\mathrm{CV}$ (Fig, 6A, B, Table 3). In the Scotia Sea in July, the situation seems to be similar (Atkinson 1991).

Differences in the winter vertical distribution of the sexes are obvious both in Calanoides acutus CV and adults. Generally, CV and adult males were found in a thinner layer than females. The highest male concentrations roughly corresponded in depth to the maximum temperature layer, i.e. the core of the upper WDW over most of the area. Adult males previously have been repeatedly reported to maintain rather restricted depth distribution (Atkinson 1991, Bathmann et al. 1993. Schnack-Schiel \& Hagen 1994, Lopez et al. 1993). How is this restricted distribution of males achieved? We speculate that sex-specific differences in the distribution of $C$. acutus may be related to the differences in the body size and lipid content of males and females, resulting in differences of their body density (specific weight). Pre-adult and adult

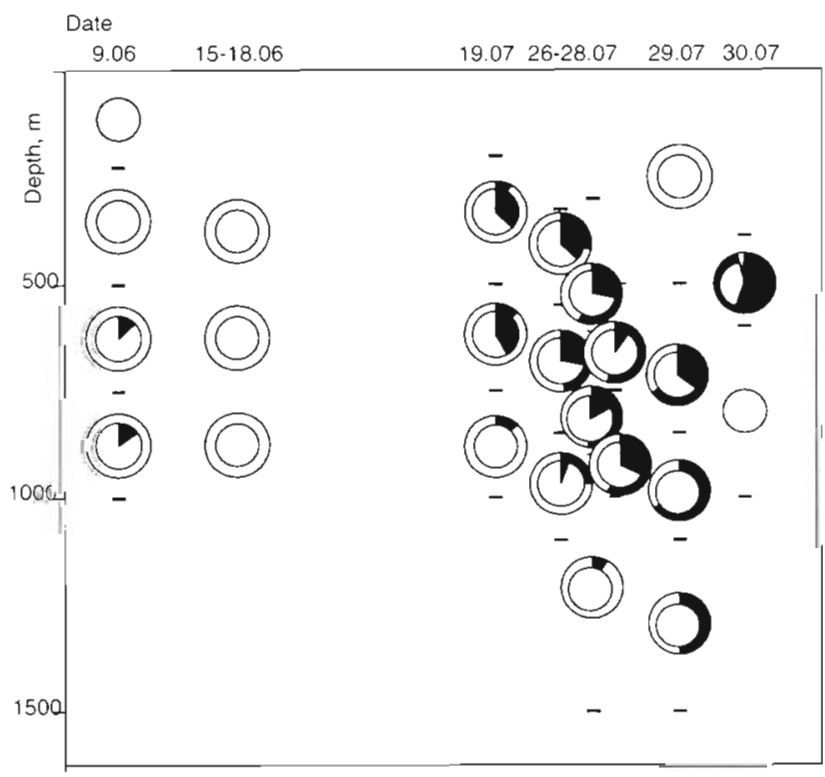

Fig. 7. Proportion of males (black sectors) and females (white sectors) in CV (inner circles) and adults (outer circles) of Calanoides acutus at various depths. Horizontal bars indicate vertical limits of sampling. Dates given as DD.MM 

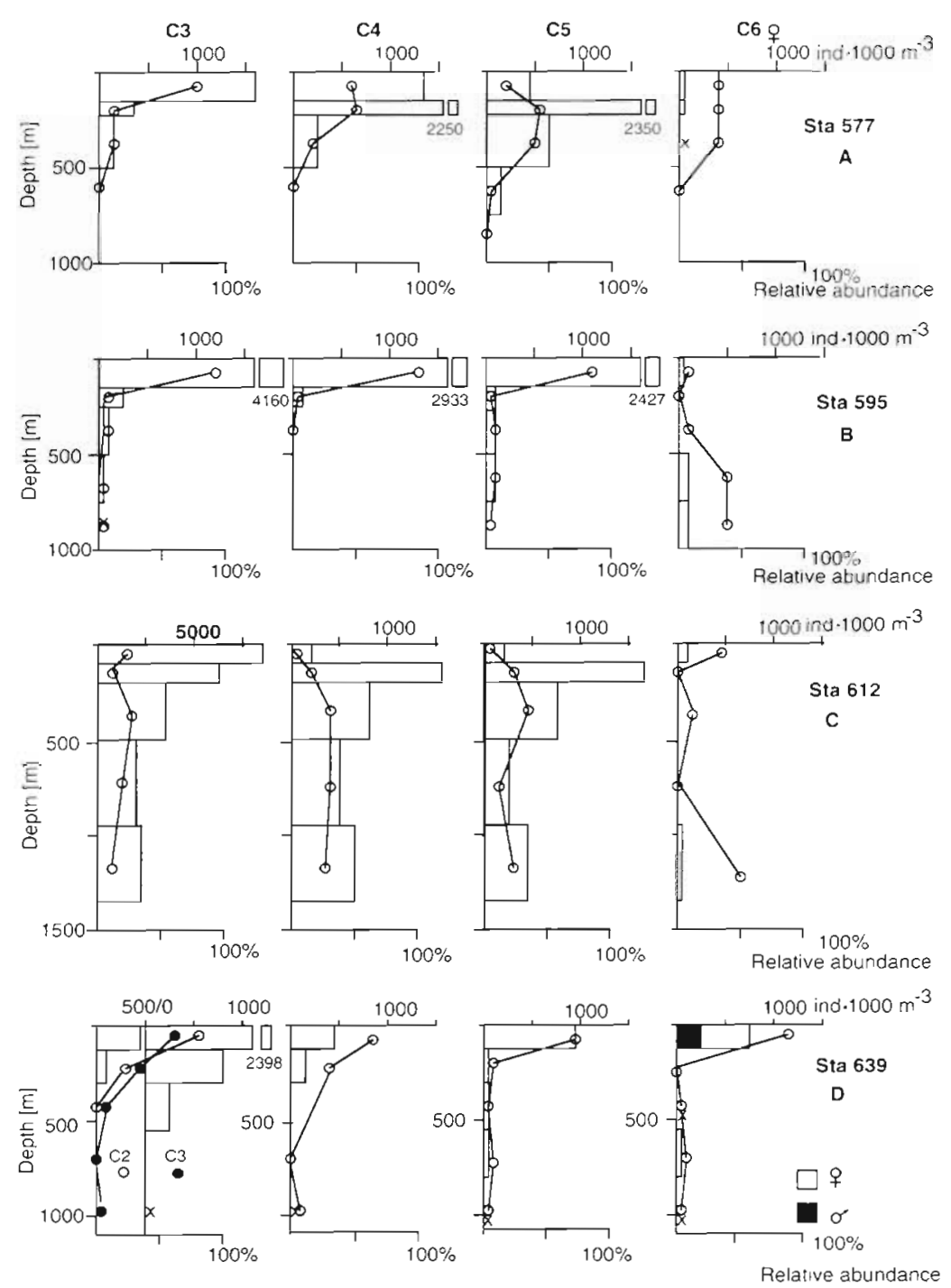

Fig. 8. Examples of the vertical distribution of Calanus propinquus. Conventions as in Fig. 5

ginal ice zone of the Scotia Sea in June-August (Hopkins et al. 1993).

On the contrary, in the Weddell Gyre interior, the bulk of the Calanus propinquus population inhabited the Winter Water (see also Bathmann et al. 1993). Just a few CIII, CV and adult female individuals occurred at depths greater than $500 \mathrm{~m}$ (Fig. 8B, D), probably resulting from a random vertical dispersion caused by natural sinking and turbulent diffusion (Rudjakov 1986). The next spring nearly the entire population of C. propinquus was observed close to the surface (Kurbjeweit 1993) which may indicate either ascent or mortality of the deep-living fraction in late winter.

A peculiar pattern of the Calanus propinquus vertical distribution in the Coastal Current zone, i.e. a dispersion of all stages throughout the water column
(Fig. 8C), also observed in this area in late winter and early spring (SchnackSchiel et al. 1991, Kurbjeweit 1994), may be a result of a complex superposition of seasonal descent, turbulent diffusion, and vertical mixing in weakly stratified waters due to the formation of polynyas.

Recent studies on the population dynamics and physiology of Calanus propinquus have suggested that it has a different life strategy compared to the other large Antarctic copepods (Schnack-Schiel et al. 1991, Bathmann et al. 1993, Drits et al. 1993). It does not have an obligatory diapause, and its copepodite stages seem to continue feeding and development in winter near the surface if food is available. The absence of a regular pattern of the vertical distribution of $C$. propinquus in winter observed during the present study supports the hypothesis that there are opportunistic tendencies in the life strategy of this species, as it has been proposed for another Antarctic species, Metridia gerlachei (Conover \& Huntley 1991).

We interpreted the distribution pattern of Rhincalanus gigas in the areas where it was relatively abundant (Weddell Front, Maud Rise area; Fig. 9) as a result of a familiar seasonal migration, i.e. a gradual descent in the course of development beginning from CIII. The absence of a regular stage-specific pattern at most stations in the Weddell Gyre coincided with a low abundance of this species. The recruitment of $R$. gigas is usually very poor in the Weddell Gyre interior (Bathmann et al. 1993, Spiridonov et al. 1996), and all stages observed there must originate from other areas. This advection may occur at different depths, leading therefore to an irregular and unpredictable vertical distribution pattern.

\section{Gonad differentiation and maturation}

In previous life cycle studies, reproduction and gonad development in the dominant Antarctic calanoids were investigated from spring to autumn with regard to the timing of the onset and duration of spawning in particular species (Ommaney 1936, Voronina 1984, Huntley \& Lopez 1990, Makarov et al. 1990, Kurbjeweit 1993, Lopez et al. 1993, Kosobokova 1994a, 
Fig. 9. Vertical distribution of temperature $\left({ }^{\circ} \mathrm{C}\right)$ and characteristics of the vertical distribution of particular copepodite stages of Rhincalanus gigas sampled to $1000 \mathrm{~m}$ depth at the Greenwich transect. Conventions as in Fig. 4; C1 to C6: copepodite stages

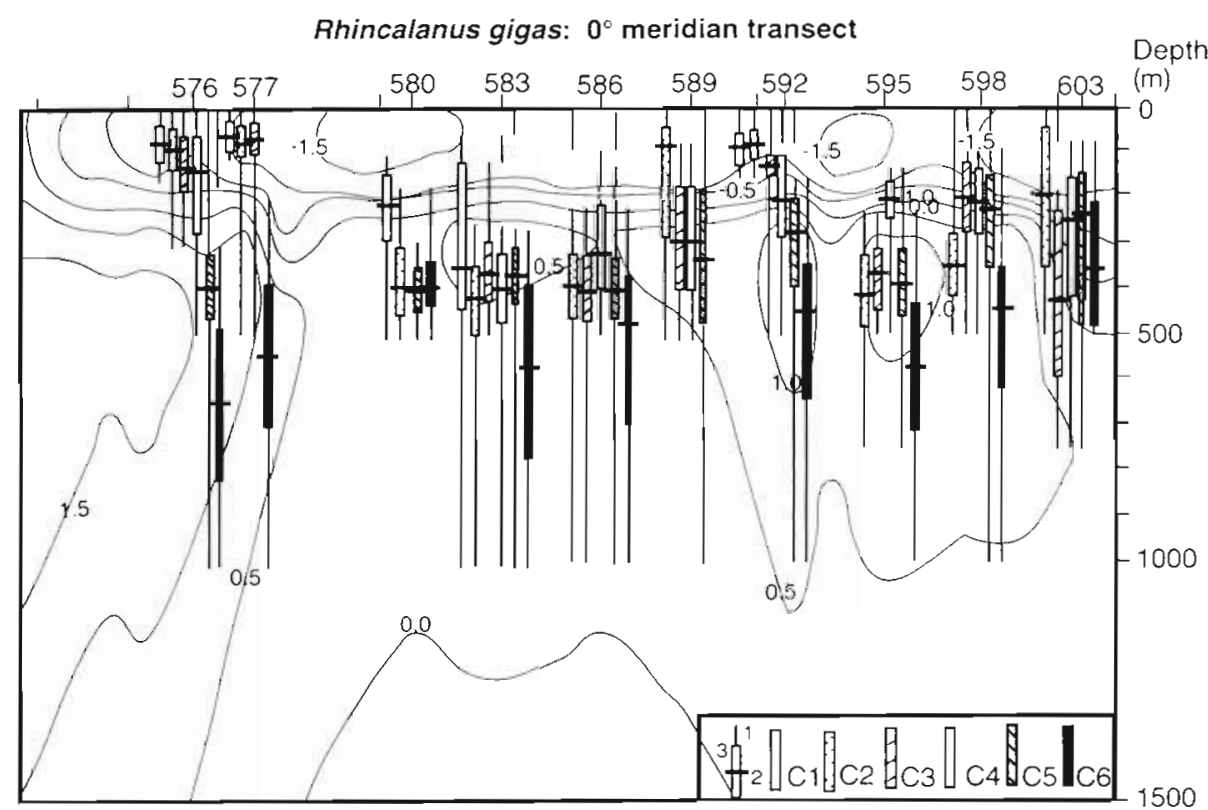

b, Schnack-Schiel \& Hagen 1995). Almost no information is available to date concerning the process of gonad maturation before spawning.

Our results indicate that the sexual differentiation in all 3 species studied and the onset of female gonad maturation in at least 2 of them take place in winter several months before the spring phytoplankton bloom. In all 3 species the sexual differentiation takes place at $\mathrm{CV}$ before molting to adult state, similar to large Arctic and subarctic calanids with long life cycles and resting overwintering stages (Marshall \& Orr 1955 Tande \& Hopkins 1981, Grigg \& Bardwell 1982, Tande et al. 1985).

At the Weddell Front, the commencement of Calanoides acutus CV sexual differentiation was observed in early June, and that may also be the case for the Weddell-Scotia Confluence area. In the Weddell Gyre interior, it is unlikely that this process starts earlier than July. The presence of $C$. acutus CV males and a somewhat higher proportion of adult males in the WeddellScotia Confluence area (Table 1) suggests that our observations coincided with the period of active molting of potential CV males to adults. This is very close to the pattern described previously for boreal-Arctic and Arctic Calanus species, in which the seasonal maximum of adult males resembled the maximum of $\mathrm{CV}$ males and almost immediately followed it (Tande \& Hopkins 1981).

Generally, adult males of Calanoides acutus are present in the population during the period of ca $4 \mathrm{mo}$ in winter-early spring (Marin 1988, Atkinson 1991 , Schnack-Schiel et al. 1991). To date, the earliest finding is that of Dearborn et al. (1986) off South Georgia
Island. They found that the brittle star Astrotoma agassizi preyed on $C$. acutus CVs and adult males in the near-bottom layer in late May-early June. The latest findings were reported in November (Gerlache Strait) by Lopez et al. (1993) and in mid-December (eastern Weddell Sea) by S. B. Schnack-Schiel (pers. comm.)

The proportion of males in the adult population strongly varies during the period of their occurrence. In the Weddell-Scotia Confluence area in July, at the time of active moulting of CVs to adults, the sex ratio of adults varied from 0.6 to 1.5 males per female (Table 1). The highest value found during the present study was 19.8 males per female north of South Shetland Islands in late July. In the southeastern Scotia Sea in late winter (August-September) Marin (1988) found that the sex ratio ranged from 8.5 to 29.8 . Bathmann et al. (1993) observed values of 0.91 to 2.80 in the Weddell Sea in late September. Later in the season in the southeastern Weddell Sea the ratios of 1.1 (October) and 0.02 (November) were found by Schnack-Schiel et al. (1991). Lopez et al. (1993) observed even lower values ranging from 0.0003 to 0.02 in the upper $290 \mathrm{~m}$ in the Gerlache Strait in November. An exceptional finding of 1 adult male among thousands of females in the northeastern Weddell Sea in early February was reported by Vervoort (1951). Such a late occurrence of a male may be considered as a deviation from the normal seasonal pattern. Thus, the major period of occurrence of Calanoides acutus males is restricted to July-October. This also appears to be the principal time of mating, which undoubtedly takes place at depth as males do not ascend to the upper layers 
(Marin 1988, Atkinson 1991, Schnack-Schiel et al. 1991, Bathmann et al. 1993).

Considerable variations of the sex ratio throughout the period of male occurrence suggest that Calanoides acutus males have a life span at the adult stage even shorter than 4 mo. Reaching adulthood in winter, they have to rely on the energy resources they accumulated in earlier copepodite stages in summer. Male maturation and further expenditures for copulation must be covered by these resources alone, because there is no food in winter and because adult males have been suggested to be not able to feed due to a reduction of their mouthparts (Vervoort 1951). Negative somatic growth when molting to adults and absence of vertical migrations indicate that the $C$ acutus male strategy is to keep stored energy for fueling the maturation process and for mating. The restricted vertical distribution of males in winter may have an adaptive value increasing success of mating when ascending females go through the layer of high male concentration during their upward spring migration (Bathmann et al. 1993). Similar depth and temporal restriction of male occurrence was also reported for the Arctic copepod Calanus hyperboreus (Conover 1965. Hirche \& Niehoff 1996).

The gonad maturation process in Calanoides acutus females starts in winter, but later than in males. Before the end of July all females throughout the studied area were definitely immature. At the end of July we observed just the very beginning of ovarian maturation near the South Orkneys where females of early maturity states (II and III) comprised about 20 to $30 \%$ of adult female total abundance. Our data indicate that the gonad maturation in females starts much earlier than has been suggested before (Andrews 1966, Hagen \& Schnack-Schiel 1996). Its first steps take place in deep water layers before the seasonal ascent of females to the surface. They apparently depend on internal energy resources in the same way as males do. However, females that have ascended might also rely on the spring phytoplanktor bloom to support the reproductive process (Lopez et al. 1993, Hagen \& Schnack-Schiel 1996).

In the 2 other species under study, Caldnus propinquus and Rhincalanus gigas, adult males can be found throughout most of the year (Marin 1988, SchnackSchiel et al. 1991, Kosobokova 1994b, Schnack-Schiel $\&$ Hagen 1995), but the highest proportion of males is found in winter, similarly to Calanoides acutus (Table 1). Sexual differentiation of CV males in both species takes place considerably before the phytoplankton bloom. Similar to $C$. acutus, the male genital system in both species becomes mature prior to maturation of females. The only case for an early commencement of maturation which we observed in $C$. propinquus females could be attributed to the development of the
South Orkney polynya (Haas et al. 1992). In R. gigas, the onset of female gonad maturation in all studied areas was found neither in June nor in July. This agrees well with the suggestion that this species commences reproduction later than C. acutus and $C$. propinquus (Voronina 1970, 1984).

\section{Conclusions}

The present study reveals profoundly different modes of vertical distribution changes in the populations of Calanoides acutus, Calanus propinquus, and Rhincalanus gigas in the Weddell Gyre in early to midwinter, along with a rather similar pattern of the winter gonad development in the first 2 species. C. acutus undergoes an ontogenetic descent which at least in CIV may last for the whole winter; sexual differentiation in $\mathrm{CV}$ begins as soon as early winter. These processes are followed by maturation of males and the onset of female maturation at depth. C. propinquus shows no indication of regular ontogenetic migration. The observed variation in vertical distribution of particular stages exhibits strong geographical variability. However, in this species the gonads of males and females begin to mature in winter as well. In the areas where the recruitment of $R$. gigas occurs, the species exhibits an ontogenetic migration which is similar to that of $C$. acutus, but the onset of maturation of females appears to be delayed until at least the end of winter.

Acknowledgements. We thank Captain $\mathrm{H}$. Jonas and the crew of RV 'Polarstern' who performed excellent work in rough weather and sea ice conditions. $M$. Schröder and A. Wisotzkl provided necessary hydrographical data. We are grateful to Drs N. M. Voromina, S. B. Schnack-Schiel, A Atkınson and J. A. Rudjakov for their valuable comments during the preparation of the manuscript and to $\mathrm{T}$ Scherzinger for help in preparation of the figures. This study was completed during the research fellowship of V.A.S. at the Alfred Wegener Institute for Polar and Marine Research in Bremerhaven, supported by the Alexander von Humboldt Foundation in 1994/95. The work of K.N.K. was supported by the International Science Foundation and by the Russian Foundation for Basic Research (RFBR Project 93-04-20124).

\section{LITERATURE CITED}

Andrews $\mathrm{KJH}$ (1966) The distribution and life history of Calanoides acutus (Giesbrecht). Discovery Rep 34 : $117-162$

Atkinson A (1.991) Life cycles of Calanoides acutus, Calanus simillimus and Rhincalanus gigas (Copepoda: Calanoida) in the Scotia Sea. Mar Biol 109:79-91

Bathmann UV, Makarov RR, Spiridonov VA, Rohardt G (1993) Winter distribution and overwintering strategies of the Antarctic copepod species Calanoides acutus, Rhincalanus gigas, and Calanus propinquus (Crustacea Calanoida) in the Weddell Sea. Polar Biol 1.3:333-346 
Beklemishev KV (1969) Ecology and biogeography of the pelagial. Nauka, Moscow

Conover RJ (1965) Notes on the molting cycle, development of sexual characters and sex ratio in Calanus hyperboreus. Crustaceana 8:308-320

Conover RJ, Huntley M (1991) Copepods in ice-covered seas-distribution, adaptation to seasonally limited food, metabolism, growth patterns and life cycle strategies in polar seas. J Mar Syst 2:1-41

Dearborn JH, Ferrari FD, Edwards KC (1986) Can pelagic aggregation cause benthic satiation: feeding ecology of the brittle star Astrotoma agassizi (Echinodermata: Ophiuroidea). Biology Antarctic Seas XVIII - Antarct Res Ser 44:1-28

Drits AV, Pasternak AF, Kosobokova KN (1993) Feeding, metabolism and body composition of the Antarctic copepod Calanus propinquus Brady with special reference to its life cycle. Polar Biol 13:13-21

Gordon AL (1967) Structure of Antarctic waters between $20 \mathrm{~W}$ and $170 \mathrm{~W}$. Antarctic Map Folio Ser - Folio $6 \mathrm{Am}$ Geogr Soc

Gouretski VV, Danilov Al (1993) Weddell Gyre: structure of the eastern boundary. Deep Sea Res 40:561-582

Grigg H, Bardwell SJ (1982) Seasonal observations on moulting and maturation in Stage $V$ copepodites of Calanus finmarchicus from the Firth of Clyde. J Mar Biol Assoc UK 62 $315-327$

Haas C, Viehoff T, Eiken H (1992) Sea-ice conditions during the Winter-Weddell-Gyre-Study 1992 ANT X/4 with RV 'Polarstern' shipboard observations and AVHRR satellite imagery. Ber Fachbereich Physik Alfred Wegener Institut 34

Hagen W (1988) Zur Bedeutung der Lipide im antarktischen Zooplankton. Ber Polarforsch 49:1-129

Hagen W, Schnack-Schiel SB (1996) Seasonal lipid dynamics in dominant Antarctic copepods: energy for overwintering or reproduction? Deep Sea Res 43:139-158

Hirche HJ (1983) Overwintering of Calanus finmarchicus and Calanus helgolandicus. Mar Ecol Prog Ser 11:281-290

Hirche HJ (1997) Life cycle of the copepod Calanus hyperboreus in the Greenland Sea. Mar Biol 128:607-618

Hirche HJ, Niehoff B (1996) Reproduction of the Arctic copepod Calanus hyperboreus in the Greenland Sea--field and laboratory observations. Polar Biol 16:209-220

Hopkins TL, Lancraft TM, Torres JJ, Donelly J (1993) Community structure and trophic ecology in the Scotia Sea marginal ice zone in winter (1988). Deep Sea Res 40: $81-105$

Huntley M, Escritor F (1991) Dynamics of Calanoides acutus (Copepoda: Calanoida) in Antarctic coastal waters. Deep Sea Res 38:1145-1167

Huntley ME, Lopez M (1990) RACER: egg production of Calanoides acutus during the spring bloom, 1989. Antarct J US 25:159-161

Kattner G, Graeve M, Hagen W (1994) Ontogenetic and seasonal changes in lipid and fatty acid/alcohol compositions of the dominant Antarctic copepods Calanus propinquus, Calanoides acutus and Rhincalanus gigas. Mar Biol 118 : $637-644$

Kosobokova KN (1994a) On the reproductive strategy of the dominant Antarctic copepods Calanoides acutus, Calanus propinquus and Rhincalanus gigas. Abstracts SCAR 6th Biol Symp Venice 1994:155

Kosobokova KN (1994b) Reproduction of the calanoid copepod Calanus propinquus in the southern Weddell Sea, Antarctica: observations in laboratory. Hydrobiologia 292/293:219-227
Kosobokova KN (in press) New data on the life cycle of Calanus glacialis in the White Sea based on the seasonal observations on the development of its genital system. Okeanologiya (in Russian)

Kosobokova KN, Drits AV, Lapina NM (1993) Changes in biochemical composition of Antarctic copepods with transition from summer to winter conditions. In: Klekowski RZ, Opalinksi KW (eds) The Second Polish-Soviet Antarctic Symposium. Inst of Ecal Publ Off, Dziekanow Lesny, p $107-116$

Kuipers B, Gonzales S (1994) Mesozooplankton biomass and egg production. In: Bathmann UV, Schulz-Baldes M, Fahrbach E. Smetacek V, Hubberten HW (eds) Die Expedition ANTARKTIS X/6-8 des FS Polarstern 1990/91. Ber Polarforsch 100:93-98

Kurbjeweit F (1993) Reproduktion und Lebenszyklen dominanter Copepodenarten aus dem Weddellmeer, Antarktis. Ber Polarforsch 129:1-238

Lemke P \{ed\} (1994) Die Expedition Antarktis X/4 mit FS 'Polarstern' Ber Polarforsch 140:1-90

Lopez MDG. Huntley ME, Lovette JT (1993) Calanoides acutus in Gerlache Strait, Antarctica. I. Distribution of late copepodite stages and reproduction during spring. Mar Ecol Prog Ser 100:153-165

Maclellan DC (1967) The annual cycle of certain calanoid species in West Greenland. Can J Zool 45:101-115

Makarov RR, Maslennikov VV, Merishenina LL (1990) Frontal zones as ecological boundaries. In: Solyankin EV Makarov RR, Danilov AI (eds) Investigations of the Weddell Gyre. Oceanographic conditions and peculiarities of the development of plankton communities. VNIRO Publication, Moscow, p 99-125 (in Russian)

Marin $\vee(1988)$ Qualitative models of the life cycles of Calanoides acutus, Calanus propinquus, and Rhincalanus gigas. Polar Biol 8:439-446

Marin V, Schnack-Schiel SB (1993) The occurrence of Rhncalanus gigas, Calanoides acutus, and Calanus propinquus (Copepoda: Calanoida) in late May in the area of the Antarctic Peninsula. Polar Biol 13:35-40

Marshall SM, Orr AP (1955) The biology of a marine copepod Calanus finmarchicus Gunnerus. Oliver and Boyd, Edinburgh

Miller CB, Cowles TJ, Wiebe PH, Copley NJ, Grigg H (1991) Phenology in Calanus finmarchicus; hypotheses about control mechanisms. Mar Ecol Prog Ser 72:79-91

Moore HB (1949) The zooplankton of the upper waters of the Bermuda area of the north Atlantic. Bull Bingham Oceanogr Collect Yale Univ 13(2):1-97

Ommaney FD (1936) Rhincalanus gigas (Brady) a copepod of the southern macroplankton. Discovery Rep 13: $227-334$

Parkinson CL (1993) Southern Ocean sea ice distribution and extents. Philos Trans R Soc Lond B Biol Sci 338:243-250

Pasternak AF, Kosobokova KN, Drits AV (1994) Feeding, metabolism and body composition of the dominant Antarctuc copepods with comments on their life cycles. Russian J Aquat Ecol 3:49-62

Rudjakov YuA (1986) Dynamics of vertical distribution of pelagic animals. Nauka, Moscow (in Russian)

Schnack-Schiel SB, Hagen W (1994) Life cycle strategies and seasonal variations in distribution and population structure of four dominant calanoid species in the eastern Weddell Sea (Antarctica). J Plankton Res 16:1543-1566

Schnack-Schiel SB, Hagen W (1995) Life-cycle strategies of Calanoides acutus, Calanus propinquus, and Metridia gerlachei (Copepoda: Calanoida) in the eastern Weddell Sea, Antarctica. ICES J Mar Sci 52:541-548 
Schnack-Schiel SB, Hagen W, Mizdalski E (1991) Seasonal comparison of Calanorde's acutus and (alanus propinquus (Copepoda: Calanolda) in the southeastern Weddell Sea, Antarctica. Mar Ecol Prog Ser 70:17-27

Schröder M. Wisotzki A, Brunken N, Hansen I, Heil P, Kreyscher M, Moschner S, Steiner N, Sterr U, Richter KU, Diedrich H (1994) Physical oceanography and nutrients. In: Lemke P (ed) Die Expedition Antarktis X/4 mit FS 'Polarstern' 1992. Ber Polarforsch 140:15-34

Smith SL, Lane PVZ (1991) The jet off Point Arena, California: its role in aspects of secondary production in the copepod Eucalanus californicus Johnson. J Geophys Res 96: $14849-14858$

Spiridonov VA, Noethig EM, Schröder M, Wisotzki A (1996) The onset of biological winter in the eastern Weddell Gyre planktonic community. J Mar Syst 9:211-230

Tande KS, Hassel A, Slagstad D (1985) Gonad maturation and possible life cycle strategies in Calanus finmarchicus and Calanus glacialis in the northwestern part of the Barents Sea. In: Gray JS, Christiansen ME (eds) Marine biology of polar regions and effects of stress on marine organisms. $\mathrm{J}$ Wiley and Sons, New York, p 141-155

Tande KS, Hopkins CCE (1981) Ecological investigations of the zooplankton community of Balsfjorden, northern Norway: genital system in Calanus finmarchicus and the role of gonad development in the overwintering strategy. Mar Biol 63:159-164

Vervoort W (1951) Plankton copepods from the Atlantic sector

Editorial responsibility: Otto Kinne,

Oldendorf/Luhe, Germany of the Antarctic. K Ned Akad Wet Verh Afd Natuurkkd Tweede Reeks 48(4):1-1.56

Vladimirskaya EV (1978) Age composition of winter populations of abundant copepod species in the southern part of the Scotia Sea. Okeanologiya 18:335-338 (in Russian)

Voronina NM (1970) Seasonal cycles of some common antarctic copepod species. In: Holdgate MW (ed) Antarctic ecology, Vol 1. Academic Press, London, p 162-172

Voronina NM (1972) The spatial structure of interzonal copepod populations in the Southern Ocean. Mar Biol 15:336-343

Voronina NM (1974) Vertical distribution of antarctic copepods Calanus propinquus and Calanoides acutus. Tr Vses Gidrobiol O-Va 20:246-269 (in Russian)

Voronina NM (1984) Ecosystems of the pelagial of the Southern Ocean. Nauka, Moscow (in Russian)

Voronina NM, Kolosova EG (1993) Seasonal reconstruction of the Antarctic plankton community. In: Voronina NM (ed) Pelagic ecosystems of the Southern Ocean. Nauka, Moscow, p 205-217 (in Russian)

Whithworth T III, Nowlin D Jr, Orsi AH, Logarnini RA, Smith SG (1994) Weddell Sea shelf water in the Bransfield Strait and Weddell-Scotia Confluence, Deep Sea Res 41: $629-641$

Zwally HG, Comiso JC, Parkinson CL, Campbell WJ, Carsey FD, Gloersen P (1983) Antarctic sea ice, 1973-1976: satellite passive-microwave observations. Sci Tech Inf Branch NASA, Washington, DC

Submitted: May 29, 1996; Accepted: June 30, 1997

Proofs received from author(s): October 7, 1997 